\section{SOME UNSOLVED PROBLEMS IN GEOLOGY ${ }^{1}$}

$M Y$ predecessor in office remarked, in the opening of his adM dress, that two courses are open to the retiring president of thi : As ociation in preparing the annual presidential discourse,he may either take up some topic relating to his own specialty, or he inay deal with various or general matters relating to science and its progress. A geologist, however, is not necessarily tied up to one or the other alternative. His subject covers the whole history of the earth in time. At the beginning it allies itself with astronomy and physics and celestial chemistry. At the end it runs into human history, and is mixed up with archæology and anthropology. Throughout its whole course it has to deal with questions of meteorology, geography, and biology. In short, there is no department of physical or biolngical science with which geology is not allied, or at least on which the geologist may not presume to trespass. When, therefore, I announce as my subject on the present occasion some of the unsolved problems of this univer:al science, you need not be surprised if I should be somewhat discursive.

Perhaps I shall begin at the utmost limits of my subject by remarking that in matters of natural and physical science we are met at the outset with the scarcely solved question as to our own place in the nature which we study, and the bearing of this on the difficulties we encounter. The organism of man is decidedly a part of nature. We place ourselves, in this aspect, in the subkingdom vertebrata, and class mammalia, and recorni e the fact that man is the terminal link in a chain of being extending throughout geological time. But the organism is not all of man ; and, when we regard man as a scientific animal, we raise a new question. If the human mind is a part of nature, then it is subject to natural law; and nature includes mind as well as matter. On the other hand, without bein $y$ absolute idealists, we may hold that mind is more potent than matter, and nearer to the real essence of things. Our seience is in any case necessarily dualistic, being the product of the reaction of mind on nature, and must be largely subjective and anthropoisorphic. Hence, no doubt, arise much of the controversy of science, and much of the unsolved difficulty. We recognise this when we divide science into that which is experimental, or depends on apparatus, and that which is observational and classificatory, - distinctions, these, which relate not $\mathrm{s}$ much to the objects of science $a_{i}$ to our methods of pursuing them. This view also opens up to us the thought that the domain of science is practically boundless; for who can set limits to the action of mind on the universe, or of the universe on mind? It follows that science must be limited on all sides by unsolved mysteries; and it will not serve any good purpose to meet these with clever guesses. If we so treat the enigmas of the sphinx Nature, we shall surely be devoured. Nor, on the other hand, must we collapse into absolute despair, and resiun ourselves to the confession of inevitable ignorance. It becomes us, rather, boldly to confront the unsolved questions of nature, and to wrestle with their difficulties till we master such as we can, and cheerfully leave those we cannot overcome to be grappled with by our successors.

Fortunately, as a geologis', I do not need to invite your attention to those transcendental questions which relate to the ultimate constitution of matter, the nature of the ethereal medium filling space, the absolute difference or identity of chemical elements, the cause of gravitation, the conservation and dissipation of energy, the nature of life, or the primary origin of bioplasmic matter. I may take the much more humble rôle of an inquirer into the unsolved or partially solved problems which meet us in considering that short and imperfect record which geology studies in the rocky layers of the earth's crust, and which leads no farther back than to the time when a solid rind had already formed on the earth and was already covered with an ocean. This record of geology covers but a small part of the history of the earth and of the system to which it belongs, nor does it enter at all into the more recondite problems involved; till it forms, I believe, some necessary preparation, at least, to the comprehension of these.

What do we know of the oldest and most primitive rocks? At this moment the question may be answered in many and di cordant ways; yet the leading elements of the answer may he given very simply. The oldest rock formation known to

Address of the retiring president of the American Association for the Advancement of Science, Principal J. W. Dawson, L.L.D., F.R.S., at Minneapolis, August I5, 1883. Advance proofs of this and othe addresses to follow have been kindly sent us by the Editor of Science. geologists is the lower Laurentian, the fundamental gneiss, the Lewisian formation of Scotland, the Ottawa gneiss of Canada. This formation of enormous thickness corresponds to what the older geologists called the fundamental granite, - a name not to be scouted, for gneiss is only a stratified granite. Perhaps the main fact in relation to this old rock is that it is a gneiss; that is, a rock at once bedded and cry talline, and havin $y$ for its dominant ingredient the mineral orthoclase, - a compound of siiica, alumina, and potash, - in which are embedded, as in a paste, grains and crystals of quartz and hornblende. We know very well, from its texture and composition, that it cannot be a product of mere beat; and, being a bedded rock, we infer that it was laid down layer by layer, in the manner of aqueous deposits. On the other hand, its chemical composition is quite d fferent from that of the muds, sands, and gravels usually deposited from water. Their special characters are caused by the fact that they have resulted from the slow decay of rocks like these gneisses, under the operation of carbonic acid and water, whereby the alkaline matter and the more soluble part of the silica have been washed away, leaving a residue mainly siliceous and aluminous. Such more modern rocks tell of dry land subjected to atmospheric decay and rainwach. If they have any direct relation to the old gneisses, they are their grandchildren, not their parents. On the contrary, the oldest gneisses show no pebbles, or sand, or limestone-notbing to indicate that there was then any land undergoing atmospheric waste, or shores with sand and gravel. For all that we know to the contrary, these old gneisses may have been deposited in a shoreless sea, holding in solution or suspension merely what it could derive from a submerged crust recently cooled from a state of fusion, still thin, and exuding here and there through its fissures heated waters and volcanic products.

It is scarcely necessary to say that I have no confidence in the supposition of unlike composition of the earth's mass on different sides, on which Dana has partly based his theory of the origin of cmtinents. The most probable conception seems to be that of Lyell; namely, a molten mass, uniform except in so far a denser material might exist towards its centre, and a crust, at first approximately even and homogeneou=, and subsequently thrown into great bendings upward and downward. This question has recently been ably discussed by Mr. Crosby in the London Geological Magazine. ${ }^{1}$

In short, the fundamental gneiss of the lower Laurentian may have been the first rock ever formed; and in any case it is a rock formed under conditions which have not since recurred, except locally. It constitutes the first and best example of these chemico-physical, aqueous, or aqueo-igneous rocks, so characteristic of the earliest period of the earth's history. Vie'sed in this way, the lower Laurentian gneiss is probably the oldest kind of rock we shall ever know,--the limit to our backward progress, beyond which there remains nothing to the geologist except physical hypotheses respecting a cooling, incandescent globe. For the chemical conditions of these primitive rocks, and what is known as to their probable origin, I must refer you to my friend Dr. Sterry Hunt, to whom we owe so much of what is known of the older crystalline rocks, ${ }^{2}$ as well as of their literature and the questions which they raise. My purpose here is to sketch the remarkable difference which we meet as we ascend into the middle and upper Laurentian.

In the next succeeding formation, the true lower Laurentian of Logan, the Grenville series of Canada, we meet with a great and significant change. It is true, we have still a predominance of gneisses which may have been formed in the same manner with those below them; but we find these now associated with great beds of limestone and dolomite, which must have been formed by the separation of calcium and magne-ium carbonates from the sea water, either by chemical precipitation or by the agency of living beings. We have also quartzite, quartzose gneisses, and even pebble beds, which inform us of sand-banks and shores. Nay, more, we have beds containing graphite, which must be the residue of plants, and iron ores which tell of the deoxidation of iron oxide by organic matters. In short, here we have evidence of new factors in world-building,- of land and ocean, of atmospheric decay of rocks, of deoxidising processes carried on by vegetable life on the land and in the waters, of lime-tone-building in the sea. To afford material for such rocks, the old Ottawa gneiss must have been lifted up into continents and mountain masses. Under the slow but sure action of the carbonic dioxide dissolved in rain water, $i$ 's felspar had crumbled

$$
\text { I June, } 1883 . \quad 2 \text { Hunt. " Essays on Chemical Geology." }
$$


down in the course of ages. Its potash, soda, lime, magnesia, and part of its silica, had been washed into the sea, there to enter into new combinations, and to form new deposits. The crumbling residue of fine clay and sand had been also washed down into the borders of the ocean, and had been there deposited in beds. ${ }^{\mathbf{1}}$ Thus the earth had entered into a new phase, which continues onward through the geological ages; and I place in your hands one key for unlocking the mystery of the world when I affirm that this great change took place, this new era was inaugurated, in the midst of the Laurentian period.

Was not this time a fit period for the first appearance of life? Should we not expect it to appear, independently of the evidence we have of the fact? I do not propose to enter here into that evidence, more especially in the case of the one well characterised Laurentian fossil, Eozoon canadense. I have already amply illustrated it elsewhere. I would merely say here, that we should bear in mind that, in this later half of the lower Laurentian or, if we so choose to style it, middle Laurentian period, we have the conditions required for life in the sea and on the land; and since in other periods we know that life was always present when its conditions were present, it is not unreasonable to look for the first traces of life in this formation, in which we find for the first time the completion of those physical arrangements which make life, in such forms of it as exist on our planet, possible.

This is also a proper place to say something of the doctrine of what is termed "metamorphism." The Laurentian rocks are undoubtedly greatly changed from their original state, more especially in the matters of crystallisation and the formation of disseminated minerals by the action of heat and heated water. Sandstones have thus passed into quartzites, clays into slates and schists, Jimestones into marbles. So far, metamorphism is not a doubtful question; but, when theories of metamorphism go so far as to suppose an actual change of one element for another, they go beyond the bounds of chemical credibility; yet such theories of metamorphism are often boldly advanced, and made the basis of important conclusions. Dr. Hunt has happily given the name "metasounatosis" to this imaginary and impossible kind of metamorphism, which may be regarded as an extreme kind of evolution, akin to some of those forms of that theory employed with reference to life, but more easily detected and exposed. I would have it to be understood that, in speaking of the metamorphi-m of the older-crystalline rocks, it is not to this metasomatosis that I refer, and that I hold that rocks which have been produced out of the materials decomposed by atmospheric erosion can never, by any process of metamorphism, be restored to the precise condition of the Laurentian rocks. Thus there is in the older formations a genealogy of rocks, which, in the absence of fossils, may be used with some confidence, but which does not apply to the more modern deposits. Still, $\mathrm{n}$ (thing in gevlozy absolutely perishes or is altogether discontinued ; and it is probable, that, down to the present day, the cattses which produced the old Laurentian gneiss may still operate in limited localities. Then, however, they were general, not exceptional. It is further to be observed that the term "gneiss" is sometimes of wide and even loose application. Beside the typical orthoclase and hornblendic gneiss of the Laurentian, there are micaceous, quartzose, garnetiferous, and many other kinds' of gneiss ; and even gneissose rocks, which hold labradorite or anorthite instead of orthoclase, are sometimes, though not accurately, included in the term.

The Grenville series, or middle Laurentian, is succeeded by what Logan in Canada called the upper Laurentian, and which other geologists have called the Norite or Norian series. Here we still have our old friends the gneisses, but somewhat peculiar in type; and associated with them are great beds rich in limefelspar, - the so-called labradorite and anorthite rocks. The precise origin of these is uncertain, but this much seems clear; namely, that they originated in circumstances in which the great limestones deposited in the lower or middle Laurentian were beginning to be employed in the manufacture, probably by aqueo-igneous agencies, of lime-felspars. This proves the Norian rocks to be much younger than the Laurentian, and that, as Logan supposed, considerable earth-movements had occurred between the two, implying lapse of time.

Next we have tbe Huronian of Logan,-a series much less crystalline and more fragmentary, and affording more evidence of land elevation and atmospheric and aqueous erosion than any

$I$ Dr. Funt has now in preparation for the press an important paper on this subject, read before the National Academy of Sciences. of the others. It has great conglomerates, some of them made up of rounded pebbles of Laurentian rocks, and others of quartz pebbles, which must have been the remains of rocks subjected to very perfect erosion. The pure quartz rocks tell the same tale, while limestones and slates speak also of chemical separation of the materials of older rocks. The Huronian evidently tells of movements in the previous Laurentian, and changes in its texture so great, that the former may be regarded as a comparatively modern rock, though vastly older than any part of the palæozoic series.

Still later than the Huronian is the great micaceous series called by Hunt the Mont Alban or White Mountain group, and the Taconian or lower Taconic of Emmons, which recalls in some measure the conditions of the Huronian. The precise relations of these to the later formations, and to certain doubtful deposits around Lake Superior, can scarcely be said to be settled, though it would seem that they are all older than the fossiliferous Cambrian rocks which practically constitute the base of the palæozoic. I have, I may say, satisfied myself, in regions which I have studied, of the existence and order of these rocks as successive formations, though I would not dogmatise as to the precise relations of those last mentioned, or as to the precise age of some disputed formations which may either be of the age of the older enzoic formations, or may be peculiar kinds of palæozoic rocks modified by metamorphism. Probably neither of the extreme views now agitated is absolutely correct.

After what has been said, you will perhaps not be astonished that a great geological battle rages over the old crystalline rocks. By some geologists they are almost entirely explained away, or referred to igneous action or to the alteration of ordinary sediments. Under the treatment of another school, they grow to great series of pre-Cambrian rocks, constituting va-t systems of formations, distinguishable from each other, not by fossils, but by differences of mineral character. I have already indicated the manner in which I believe the dispute will ultimately be settled, and the president of the geological section will treat it more fully in his opening address.

After the solitary appearance of Eozoon in the Laurentian, and of a few uncertain forms in the Huronian and Taconian, we find ourselves in the Cambrian, in the presence of a nearly complete invertebrate famna of protozoa, polyp:, echinoderms, mollusks, and crustacea; and this not confined to one locality merely, but apf arently extended simultaneou-ly throughout the ocean. This sudden incoming of animal life, along with the subsequent introdiction of successive groups of invertebrates, and finally of vertebrate animals, furnishes one of the greatest of the unsolved problems of geology, which geologists were wont to settle by the supposition of successive creations. In an address delivered at the Detroit meeting of the Association in I 875 , I endeavoured to set forth the facts as to this succession, and the general principles involved in it, and to show the insufficiency of the theories of evolution suggested by biologists to give any substantial aid to the geologist in these questions. In looking again at the points there set forth, I find they have not been invalidated by subsequent discoveries, and that we are still nearly in the same position with respect to these great questions that we were in at that time, - a singular proof of the impotency of that deductive method of reasoning which has become fashionable among naturalists of late. Yet the discussions of recent years have thrown some additional light on these matters; and none more so than the mild disclaimers with which my friend Dr. Asa Gray and other moderate and scientific evolutionists have met the extreme views of such men as Romanes, Haeckel, Lubbock, and Grant Allen. It may be useful to note some of these as shedding a little light on this dark corner of our unsolved problems.

It has been urged, on the side of rational evolution, that this hypothesis does not profess to give an explanation of the absolute origin of life on our planet, or even of the original organisation of a single cell or of a simple mass of protoplasm, living or dead. All experimental attempts to produce by synthesis the complex albuminous substances, or to obtain the living from the non-living, have so far been fruitless; and, indeed, we cannot imagine any process by which such changes could be effected. That they have been effected we know; but the process employed by their maker is still as mysterious to us as it probably was to him who wrote the words, "And God said, Let the waters swarm with swarmers." How vast is the gap in our knowledge and our practical power implied in this admission, which must, however, be made by every mind not absolutely 
blinded by a superstitious belief in those forms of words which too often pass current as philosophy.

But if we are content to start with a number of organisms ready made, - - a somewhat humiliating start, however,--we still have to ask, How do these vary so as to give new species? It is a singular illusion in this matter, of men who profess to be believers in natural law, that variation may be boundless, aimless, and fortuitous, and that it is by spontaneous selection from varieties thus produced that development arises. But surely the supposition of mere chance and magic is unworthy of science. Varieties must have causes, and their causes and their effects must be regulated by some law or laws. Now, it is easy to see that they cannot be caused by a mere innate tendency in the organism itself. Every organism is so nicely equilibrated, that it has no such spontaneous tendency, except within the limits set by its growth and the law of its periodical clianges. There may however, be equilibrium more or less stable. I believe all attempts hitherlo made have failed to account for the fixity of certain, nay, of very many, types throughout geological time; but the mere consideration that one may be in a more stable state of equilibrium than another so far explains it. A rocking stone has no more spontaneou; tendency to move than an ordinary boulder, but it may be made to move $u$ ith a touch. So it probably is with organisms. But, if so, then the causes of variation are external, as in many cases we actually know them to be; and they must depend on instability or change in surroundings, and this so arranged as not to be too extreme in amount, and to operate in some determinate direction. Observe how remarkable the unity of the adjustments involved in such a supposition. How superior they must be to our rude and always more or less unsuccessful attempts to produce and carry furward varieties and races in definite directions! This cannot be chance. If it exists, it must depend on plans deeply laid in the nature of things, else it would be most monstrous magic and causeless miracle. Still more certain is this conclusion when we consider the vast and orderiy succession made known to us by geology, and which must have been regulated by fixed laws, only a few of which are as yet known to us.

Beyond these general considerations, we have others of a more special character, based on palæontological facts, which show how imperfect are our attempts, as yet, to reach the true causes of the introduction of genera and species.

One is the remarliable fixity of the leading types of living beings in geological time. If instead of framing, like Haeckel, fanciful phylogenies, we take the trouble, with Barrande and Gaudry, to trace the forms of life through the period of their existence, each along its own line, we shall be greatly struck with this, and especially with the continuous existence of many low types of life through vicissitudes of physical conditions of the most stupendous character, and over a lapse of time scarcely conceivable. What is still more remarkable is, that this holds in groups which, within certain limits, are perhaps the most variable of all. In the present world no creatures are individu. ally more variable than the protozoa; as, for example, the foraminifera and the sponges. Yet these groups are fundamentally the same from the beginning of the palæozoic until now; and modern species seem scarcely at all to differ from speciuens procured from rocks at least half way back to the beginning of our geolngical record. If we suppose that the present sponges and foraminifera are the descendants of those of the Silurian period, we can affirm, that, in all that vast lapse of time, they hive, on the whole, made little greater change than that which may be observed in variable forms at present. The same remark applies to other low animal forms. In forms somewhat higher and less variahle, this is equally noteworthy. The pattern of the venation of the wings of cockroaches, and the structure and form of land-snail; , gally-worms, and decapod crustaceans, were all settled in the Carboniferous age in a way that still remains. So were the foliage and the fructification of club-mosses and ferns. If at any time members of these groups branched off, so as to lay the foundation of new species, this must have been a very rare and exceptional occurrence, and one demanding even some suspension of the ordinary laws of nature.

Certain recent utterances of eminent scientific men in England and France are most instructive with reference to the difficulties which encompass this subject. Huxley, at present the leader of English evolutionists, in his "Rede Lecture" 1 delivered at Cambridge, England, holds that there are only two "possiple alternative hypotheses" as to the origin of species,-(I) that of

$$
{ }^{x} \text { Report in NATURa, June } 2 x \text { (p. } x 87 \text { ), corrected by the author. }
$$

"construction," or the mechanical putting-together of the materials and parts of each new species separately ; and (2) that of "evolution," or that one form of life "proceeded from another" by the "establishment of small successive differences." After comparing these modes, much to the disadvantage of the first, he concludes with the statement that "this was his case for evolution, which he rested wholly on arguments of the kind he had adduced;" these arguments being the threadbare false analogy of ordinary reproduction and the transformation of species, and the mere succession of forms more or less similar in geological time, neither of them having any bearing whatever on the origin of any species or on the cause of the observed succession. With reference to the two alternatives, while it is true that no certain evidence has yet been obtained-either by experiment, observation, or sound induction-as to the mode of origin of any species, enough is known to show that there are numerous possible methods, grouped usually under the beads of absolute creation, mediate creation, critical evolution, and gradual evolution. It is also true that almost the only thing we certainly know in the matter is that the differences characteristic of classes, orders, genera, and species, must have arisen, not in one or two, but in many ways. An instructive commentary on the capacity of our age to deal with these great question; is afforded by the fact that this little piece of clever mental gyomastics should have been practised in a university lecture and in presence of an educated audience. It is also deserving of notice, thit, thourh the lecturer takes the development of the Nautili and their allies as his principal illustration, he evidently attaches no weight to the argument in the opposite sense deduced by Barrande-the man of all others most profoundly acquainted wi:h these animals -from the palæozoic cephalopods.

Another example is afforded by a lecture recently delivered at the Royal Institution in London by Professor Flower. ${ }^{1}$ The subject is "The Whales, Past and Present, a"d their Probable Origin," The latter point, as is well known, Gaudry had candidly given up. "We have questioned," he says, "these strange and gigantic sovereigns of the tertiary ocean : as to their ancestors, - they leave us without reply." Flower is bold enough to face this problem; and he does so in a fair and vigorous way, though limiting himself to the supposition of slow and gradual change. He gives up at once, as every anatomist must, the idea of an origin from fishes or reptiles. He thinks the ancestors of the whales must have been quadrupedal mammals. He is obliged for good reasons to reject the seals and the otters, and turns to the ungulates, though here, also, the difficulties are formidable. Finally he has recourse ts an imaginary ancestor, supposed to have haunted marshes and rivers of the mesozoic age, and to have been intermediate between a hippopotamus and a dolphin, and omnivorous in diet. As this animal is altogether unknown to geology or zoology, and not much less difficult to account for than the whales themselves, he very properly adds, "Please to recollect, however, that this is a mere speculation." He trusts, however, that such speculations are "not without th-ir use", but this will depend upon whether or not they lead men's minds from the path of legitimate science into the quicksands of baseless conjecture.

Gaudry, in his recent work, "Enchaînements du Monde Animal," 2 though a sirong advocate of evolution, is obliged in his final résumé to say, "Il ne laisse point percer le mystère qui entoure le developpement primitif des grandes clasies du monde animal. Nul homme ne sait comment ont été formés les premiers individus de foraminifêres, de polypes, d'étoiles de mer, de crinoides, \&c. Les fossiles primaires ne nous ont pas encore fourni de preuves positives du passage des animaux d'une classe à ceux d'une autre classe."

Professor Williamson of Manchester, in an address delivered in February last before the Royal Institution of Great Britain, after showing that the conifers, ferns, and lycopods of the palæozoic have no known ancestry, use; the significant words, "The time has not yet arrived for the appointment of a botanical kingat-arms and constructor of pedigrees."

Another caution which a palæontol gist bas occa:ion to give with regard to theorits of life has reference to the tendency of biologist: to infer that animals and plants were introduced under embryonic forms, and at first in few and imperfect specie: Facts do not substantiate this. The first appearance of leading types of life is rarely embryonic. On the contrary, they o ten appear in highly perfect and specialised for ns ; often, however, of composite type, and expressing characters afterwards s?

$$
\text { I Reported in Nature. } 2 \text { Paris, } 1883 .
$$


separated as to belong to higher groups. The trilobites of the Cambrian are some of them of few segments, and, so far, embryonic; but the greater part are many-segmented, and very complex. The batrachians of the carboniferous present many characters hisher than those of their modern successors, and now appropriated to the true reptiles. The reptiles of the Permian and trias usurped some of the prerogatives of the mammals. The ferns, lycopods, and equisetums of the Devonian and carboniferous were, to say the least, not inferior to their modern representatives. The shell-bearing cephalopods of the palrozjic would seem to have possessed structures now special to a higher group, that of the cuttle-fishes. The bald and contemptuous negation of these facts by Haeckel and other biologists does not tend to give geologists much confidence in their dicta.

Again: we are now prepared to say that the struggle for existence, however plau-ible as a theory, when put before us in connection with the productiveness of animals, and the few survivors of their multitudinons progeny, has not been the determining cause of the introduction of new species. The periods of rapd introduction of new forms of marine life were not periods of strugsle but of expansion, - those periods in which the submergence of continents afforded new and large space for their extension and comfortable subsistence. In like manner it was continental emergence that afforded the opportunity for the introduction of land animals and plants. Further, in con. nection with this, it is now an established conclusion that the great aggressive faunas and floras of the continents have originated in the nortb, some of them within the Arctic circle; and this in periods of exceptional warmth, when the perpetual summer sunshine of the Arctic regions coexisted with a warm temperature. The testimony of the rocks thus is, that not struggle, but expansion, furnished the requisite conditions for new forms of life, and that the periods of struggle were characterised by depauperation and extinction.

But we are sometimes told that organisms are merely mechanical, and that the discussions respecting their origin have no significance, any more than if they related to rocks or crystals, because they relate merely to the organism considered as a machine, and not to that which may be supposed to be more important, namely, the great determining power of mind and will. That this is a mere evasion, by which we really gain nothing, will appear from a characteristic extract from an article by an eminent biologist, in the new edition of the "Encyclopædia Britannica,"- a publication which, I am sorry to say, in tead of its proper rôle as a repertory of facts, has become a strong partisan, stating extreme and unproved speculations as if they were conclusions of science. The statement reterred to is as follows: "A mass of living protoplasm is simply a molecular machine of great complexity, the total results of the working of which, or its vital phenomena, depend on the one hand on its construction, and, on the other, on the energy sup lied to it; and to speak of vitality as anything but the name for a series of operations is as if one should talk of the horologity of a clock." It would, I think, scarcely be possible to put into the same number of words a greater amount of unscientific assumption and unproved statement than in this sentence. Is "living protoplasm" different in any way from dead protoplasm, and, if so, what causes the difference? What is a "machine"? Can we conceive of a self-produced or uncaused machine, or one not intended to work out some definite results? The results of the machine in question are said to be "vital phenomena ;" certainly most wonderful results, and greater than those of any machine man has yet been able to construct. But why "vital"? If there is no such thing as life, surely they are merely physical results. Can mechanical causes produce other than physical effects? To Aristotle, life was "the cause of form in organisms." Is not this quite as likely to be true as the converse proposition? If the vital phenomena depend on the "construction" of the machine, and the "energy supplied to it," whence this ccnstruction, and whence this eneryy ? The illustration of the clock does not help us to answer this question. The construction of the clock depends on its maker, and its energy is derived from the hand that winds it up. If we can think of a clock which no one has made and which no one winds, a clock constructed by chance, set in harmony with the universe by chance, wound up periodically by chance,- - we shall then have an idea parallel to that of an organism living, yet without any vital energy or creative law ; but in such a case we should certainly have to assume some antecedent cause, whether we call it " horologity" or by some other name. Perhaps the term "evolution" would serve as well as any other, were it not that common sense teaches that nothing can be spontaneously evolved out of that in which it did not previously exist.

There is one other unsolved problem, in the study of life by the geologist, to which it is still necessary to advert. This is the inability of palrontology to fill up the gaps in the chain of being. In this respect, we are constantly taunted with the imperfection of the record; but facts show that this is much more complete than is generally supposed. Over long periods of time and many lines of being we have a nearly continuous chain; and, if this does not show the tendency desired, the fault is as likely to be in the theory as in the record. On the other hand, the abrupt and simultaneous appearance of new types in many specific and generic forms, and over wide and separate areas at one and the same time, is too often repeated to be accidental. Hence palæontologists, in endeavouring to establish evolution, have been obliged to assume periods of exceptional activity in the introduction of specie;, alternating with others of stagnation,- - a doctrine differing very little from that of special creation as held by the older geoloyists.

The attempt has lately been made to account for these breaks by the assumption that the geological record relates only to periods of submergence, and gives no information as to those of elevation. This is manifestly untrue. In so far as marine life is concerned, the periods of submergence are those in which new forms abound for very obvious reasons already hinted. But the periods of new forms of land and fresh-water life are those of elevation, and thase have their own records and monu. ments, often very rich and ample; as, for example, the swamps of the carboniferous, the transition from the cretaceous subsidence to the Laramie elevation, the tertiary lake-basins of the west, the terraces arid raised beaches of the pleistocene. Had I time to refer in detail to the breaks in the continuity of life which cannot be explained by the imperfection of the record, I could show at least that nature, in this case, does advance fer saltum, - by leaps, rather than by a slow continuous process. Many able reasoners, as Le Conte in this country, and Mivart and Collard in England, hold this view.

Here, as elsewhere, a vast amount of steady conscientious work is required to enable us to solve the problems of the history of life. But, if so, the more the hope for the patient student and investigator. I know nothing more chilling to research, or unfavourable to progress, than the promulgation of a dogmatic decision that there is nothing to be learned but a merely fortuitous and uncaused succession, amenable to no law, and only to be covered, in order to hide its shapeless and uncertain proportions, by the mantle of bold and gratuitous hypothesis.

So soon as we find evidence of continents and oceans, we raise the question, "Have these continents existed from the first in their present position and form, or have the land and water changed places in the course of geological time?" In reality both statements are true in a certain limited sense. On the one hand, any geological map whatever suffices to show that the general outline of the existing land began to be formed in the first and oldest crumplings of the crust. On the other hand, the greater part of the surface of the land consists of marine sediments which must have been derived from land that has perished in the process, while all the continental surfaces, except, perhaps, some high peaks and ridges, have been many times submerged. Both of these apparently contradictory statements are true; and, without assuming both, it is impossible to explain the existing contours and reliefs of the surface.

In the case of North America, the form of the old nucleus of Laurentian rock in the north already marks out that of the finished continent, and the successive later formations have been laid upon the edges of this, like the successive loads of earth dumped over an embankment. But in order to give the great thickness of the palæozoic sediments, the land must have been again and again submerged, and for long periods of time. Thus, in one sense, the continents have been fixed; in another, they have been constantly fluctuating. Hall and Dana have well illustrated these points in so far as eastern North America is concerned. Professor Hull of the Geological Survey of Ireland has recently had the boldness to reduce the fluctuations of land and water, as evidenced in the British Islands, to the form of a series of maps intended to show the physical geography of each successive period. The attempt is probably premature, and has been met with much adverse criticism; but there can be no doubt that it has an element of truth. When we attempt to calculate what could have been supplied from the old eozoic 
nucleus by decay and aqueous erosion, and when we take into account the greater local thickness of sediments towards the present sea-basins, we can scarcely avoid the conclusion that extensive areas once occupied by high land are now under the sea. But to ascertain the precise areas and position of these perished lands may now be impos ible.

In point of fact, we are obliged to believe in the contemporaneous existence in all geological periods, except perhaps the very oldest, of three sorts of areas on the surface of the earth : I. Oceanic areas of deep sea, which must always have occupied the bed of the present ncean, or parts of it ; 2 . Continental plateaus, sometimes existing as low flats or as higher tablelands, and sometimes submerged; 3. Areas of plication or folding, more especially along the borders of the oceans, forming elevated lands rarely submerged, and constantly affording the material of sedimentary accumulations.

Every geologist knows the contention which bas been occasioned by the attempts to correlate the earlier palæozoic deposits of the Atlantic margin of North America with those forming at the same time on the interior plateau, and with those of intervening lines of plication and igneouts disturbance. Stratigraphy, lithology, and fossils are all more or less at fault in dealing with these questions; and, while the general nature of the problem is understool by many geologists, its solution in particular cases is still a source of apparently endless debate.

The causes and mode of operation of the great movements of the earth's crust which have produced mountains, plains, and tableland;, are still involved in some mystery. One patent cause is the unequal settling of the crust towards the centre ; but it is not so generally understood as it should be that the greater settlement of the ocean bed has necessitated its pressure against the sides of the continents in the same manner that a huge icefloe crushes a ship or a pier. The geological map of North A merica shows this at a glance, and impresses us with the fact that large portions of the earth's crust have not only been folded, but bodily pushed back for great distances. On looking at the extreme north, we see that the great Laurentian mass of central Newfoundland has acted as a protecting pier to the space immediately west of it, and has caused the Gulf of St. Lawrence to remain an undisturbed area since palæozoic times. Immediately to the south of this, Nova Scotia and New Brunswick are folded back. Still farther south, as Guyot has shown, the old sediments have been crushed in sharp folds against the Adirondack mass, which has shelteret the tableland of the Catskills and of the Great Lakes. South of this again, the rocks of Pennsylvania and Maryland have been driven back in a great curve to the west. Nothing, I think, can more forcibly show the enormous pressure to which the edges of the continents have been exposed, and at the same time the great sinking of the ocean beds. Complex and difficult to calculate though these movements of plica. tion are, they are more intelligible than the apparently regular pulsations of the flat continental areas, whereby they have alternately been below and above the waters, and which must have depended on somewhat regular recurring causes, connected either with the secular cooling of the earth, or with the gradual retardation of its rotation, or with both. Throughout these changes, each successive elevation exposed the rocks for long ages to the decomposing influence of the atmosphere. Each submergence swept away, and deposited as sediment, the material accumalated by decay. Every change of elevation was accoinpanied with changes of climate and with modifications of the habitats of animals and plants. Were it possible to restore accurately the physical geography of the earth in all these respect:, for each geological period, the data for the solution of many difficult questions would be furnished.

It is an unfortunate circumstance that conclusions in geology arrived at by the most careful observation and induction do not remain undisturbed, but require constant vigilance to prevent them from being overthrown. Sometimes, of course, this arises from new discoveries throwing new light on old facts; but when this occurs it rarely works the complete subversion of previously received views. The more usual case is, that some over-zeal ou specialist suddenly discovers what seems to him to overturn all previous beliefs, and rushes into print with a new and plausible theory, which at once carries with him a host of half-informed people, but the insufficiency of which is speedily made manifest.

Had I written this address a few years ago, I might have referred to the mode of formation of coal as one of the things most surely settled and understood. The labours of many eminent geologists, microscopists, and chemists in the Old and the New Worlds bad shown that coal nearly always rests upon old soil surfaces penetrated with roots, and that coal-beds have in their roofs erect trees, the remains of the last forests that grew upon them. Lcgan and I have illustrated this in the case of the series of more than sixty successive coal-beds exposed at the South Joggins, and have shown unequivocal evidence of landsurfaces at the time of the deposition of the coal. Microscopical examination has proved that these coals are composed of the materials of the same trees whose roots are found in the underclays, and their stems a: d leaves in the roof shales; that much of the material of the coal has teen subjected to sub-aërial decay at the time of its accumulation; and that, in this, ordinary coal differs from bituminous shale, earthy bitumen, and some kinds of cannel, which have been formed under water ; that the matter remaining as coal consists almost entirely of epidermal tissues, which, being suberose in character, are highly carbonaceous, very durable, and impermeable by water, ${ }^{\mathrm{I}}$ and are hence the best fitted for the production of pure coal; and finally that the vegetation and the climatal and geographical features of the coal period were eminently fitted to prcduce in the vast swamps of that period precisely the effects observed. All these points and many others have been thoroughly worked out for both European and American coal-fields, and seemed to leave no doubt on the subject. But several years ago certain microscopist s observed on slices of coal layers filled with spore-cases, - a not unusual circumstance, since these were shed in vast abundance by the trees of the coal forests, and because they contain suberose matter of the same character with epidermal tissues generally. Immediately we were informed that all coal consists of spores ; and, this being at once accepted by the unthinking, the results of the labours of many years are thrown aside in favour of this crude and partial theory. A little later, a German microscopist has thought proper to describe coal as inade up of minute algæ, and tries to reconcile this view with the appearances, devising at the same time a new and formidable nomenclature of generic and specific names, which would seem largely to represent mere fragments of tissues. Still later, some local facts in a French coal-field have induced an eminent botanist of that country to revive the drift theory of coal, in opposition to that of growth in situ. A year or two ago, when my friend Professor Williamson of Manchester imformed me that he was preparing a large series of slices of coal with the view of revising the whole subject, I was inclined to say that, after what had been done by Lyell, Goeppert, Logan, Hunt, Newberry, and myself, this was scarcely necessary ; but, in view of what I have just stated, it may be that all he can do will be required to rescue from total ruin the results of our labours.

An illustration of a different character is afforded by the controversy now raging with respect to the so-called fucoids of the ancient rocks. At one time the group of fucoids, or algæ, constituted a general place of refuge for all sorts of unintelligible forms and markings; graptolites, worm-trails, crustacean tracks, shrinkage-cracks, and, above all, rill-marking, forming heterogeneous group of fucoidal remains distinguished by generic and specific names. To these were also added some true landplants badly preserved, or exhibiting structures not well understood by botanists. Such a group was sure to be eventually dismembered. The writer has himself done something toward this, ${ }^{2}$ but Professor Nathorst has done still more; ${ }^{3}$ and now some intelligible explanation can be given of many of these forms. Quite recently, however, the Count de Saporta in an elaborate illustrated memoir, 4 bas come to the defence of the fucoids, more especially against the destructive experiments of Nathorst, and would carry back into the vegetable kingdom many things which would seem to be mere trails of animals. While writing this address, I have received from Professor Crié of Rennes a paper in which he not only supports the algal nature of $\mathrm{Ru}$ ichnites, Arthrichnites, and many other supposed fucoids, but claims for the vegetable kingdom even Receptaculites and Archæocyatbus, It is not to be denied that some of the facts which he cites, respecting the strticture of the Siphoniæ and of certain modern incrusting algæ, are very suggestive, though I cannot agree with his conclusions. My own experience has convinced me that, while non-botanical geologists are prone to mistake all kinds of

× "Acadian Geology," third edition, supplement,.p. 68. .

2 "Footprints and Impressions on Carboniferous Rocks," Amer. Journ. Sc,,$\times 873$.

3 Royal Swedish Academy, Stockholm, x881

4 "Apropos des Alyues Fossiles," Paris, $x 88_{3}$. 
markings for plants, even good botanists, when not familiar with the chemical and mechanical condition : of fos:ilisation, and with the present phenomena of tidal shores, are quite as easily misled, though they are very prone, on the other hand, to regard land1 lants of some complexity, when badly pre erved, as mere algæ. In these circumstances it is very difficult to secure any consensus, and the truth is only to be found by careful observation of competent men. One trouble is that these usually obscure markings have heen despised by the greater number of palæontologists, and probably would not now be so much in controversy were it not for the use made of them in illustrating supposed phylogenies of plants.

It would be wrong to close this address without some reference to that which is the veritable pons asinorum of the science, the great and nuch debated glacial period. I trust that you will not : uppose that, in the end of an hour's address, I am about to discuss this vexed question. Time would fail me even to name the hosts of recent authors who have contended in this arena. I can hope only to point out a few landmarks which may aid the geological adventurer in traversing the slippery and 1reacherous surface of the hypothetical ice-sheet of pleistocene times, and in avoiding the yawning crevasses by which it is traversed.

No conclusions of geology seem more certain than that great changes of climate have occurred in the course of geological time; and the evid nce of this in that comparatively modern period which immediately preceded the human age is so striking that it has come to be known as preeminently the ice age, while, in the preceding tertiary periods, temperate conditions seem to have prevailed even to the Pole. Of the many theories as to these changes which have been proposed, two seem at present to divide the suffrages of geologists, either alone, or combined with each other. These are, (I) the theory of the precession of the equinoxes in connection with the varying eccentricity of the earth's orbit, advocated more especially by Croll ; and (2) the different distribution of land and water as affecting the reception and radiation of heat and the ocean currents, - a theory ably propounded by Lyell, and subsequently extensively adopted, either alone or with the previous one. One of these views may be called the astronomical; the other, the geographical. I confess that I aw inclined to accept the second or Lyellian theory for such reasons as the following : 1. Great elevations and depressions of land have occurred in and since the pleistocene, while the alleged astronomical changes are not certain, more especially in regard to their probable effect on the earth; 2 . When the rival theories are tested by the present phenomena of the Soutbern Polar region and the North Atlantic, there seem to be geographical causes adequate to account for all except extreme and unproved glacial conditions; 3 . The astronomical cause would suppose regularly recurring glacial periods of which there is no evidence, and it would give to the latest glacial age an antiquity which seems at variance with all other facts ; 4 . In those more northern regions where glacial phenomena are most pronounced, the theory of floating sheets of ice, with local glaciers descending to the sea, seems to meet all the conditions of the case; and these would be obtained, in the North Atlantic at least, by very moderate changes of level, causing, for example, the equatorial current to flow into the Pacific, instead of running northward as a gulf stream ; 5 . The geographical theory allows the supposition not merely of vicissitudes of climate quickly following each other in unison with the movements of the surface, but allow's also of that near local approximation of regions wholly covered with ice and snow, and others comparatively temperate, which we see at present in the north.

If, however, we are to adopt the geographical theory, we must avoid extreme views; and this leads to the inquiry as to the evidence to be found for any such universal and extreme glaciation as is demanded by some geologists.

The only large continental area in the northern hemisphere supposed to be entirely ice and snow clad is Greenland; and this, so far as it goes, is certainly a local case, for the ice and snow of Greenland extend to the south as far as $60^{\circ} \mathrm{N}$. latitude, while both in Norway and in the interior of North America the climate in that latitude permits the growth of cereals. Further, Grinnel Land, which is separated from North Greenland only by a narrow sound, has a comparatively mild climate, and, as Nares has shown, is covered with verdure in summer. Still further, Nordenskjöld, one of the most experienced Arctic explorers, holds that it is probable that the interior of Greenland is itself verdant in summer, and is at this moment preparing to attempt to reach this interior oasis. Nor is it difficult, with the aid of the facts cited by Woeikoff and Whitney, ${ }^{1}$ to perceive the cause of the exceptional condition of Greenland. To give ice and snow in large quantities, two conditions are required,first, atmospheric humidity ; and, secondly, cold precipitating regions. Both of these conditions meet in Greenland. Its high coast-ranges receive and condense the humidity from the sea on both sides of it and to the south. Hence the vast accumulation of its coast snow-fields, and the intense discharge of the glaciers emptying out of its valleys. When extreme glacialists point to Greenland, and ask us to believe that in the glacial age the whole continent of North America as far south as the latitude of $40^{\circ}$ was covered with a continental glacier, in some places several thousands of feet thick, we may well ask, first, what evidence there is that Greenland, or even the Antarctic continent, at preseut shows such a condition; and, secondly, whether there exists a possibility that the interior of a great continent could ever receive so large an amount of precipitation as that required. So far as present knowledge exists, it is certain that the meteorologist and the physicist must answer both questions in the ne ative. In short, perpetual snow and glaciers must be local, and cannot be continental, because of the vast amount of evaporation and conden ation required. These can only be possible where comparatively warm seas supply moisture to cold and elevated land; and this supply cannot, in the nature of things, penetrate far inland. The actual condition of interior Asia and interior America in the higher northern latitudes affords positive proof of this. In a state of partial submergence of our northern continents, we can readily imagine glaciation by the combined action of local glaciers and great ice-floes; but, in whatever way the phenomena of the boulder clay and of the so-called terminal moraines are to be accounted for, the theory of a continuous continental glacier must be given up.

I cannot better indicate the general bearing of facts, as they present themselves to my mind in connection with this subject, than by referring to a paper by Dr, G. M. Dawson on the distribution of drift over the great Canadian plains east of the Rocky Mountains. ${ }^{2}$ I am the more inclined to refer to this, because of its recency, and because I have so often repeated similar conclusions as to eastern Canada and the region of the Great Lakes.

The great interior plain of western Canada, between the Laurentian axis on the east and the Rocky Mountains on the west, is seven hundred miles in breadth, and is covered with glacial drift, presenting one of the greatest examples of this deposit in the world. Proceeding eastward from the base of the Rocky Mountains, the surface, at firse more than four thousand feet above the sea-level, descends by successive steps to twentyfive hundred feet, and is based on cretaceous and Laramie rocks, covered by boulder clay and sand, in some places from one hundred to two bundred feet in depth, and filling up preexisting hollows, though itself sometimes piled into ridges. Near the Rocky Mountains the bottom of the drift consists of gravel not glaciated. This extends to about one bundred miles east of the mountains, and must have been swept by water out of their valleys. The boulder clay resting on this deposit is largely made up of local debris, in so far as its paste is concerned. It contains many glaciated boulders and stones from the I.aurentian region to the east, and also smaller pebbles from the Rocky Mountains; so that at the time of its formation there must have been driftage of large stones for seven hundred miles or more from the east, and of smaller stones from a less distance on the west. The former kind of material extends to the base of the mountains, and to a height of more than four thousand feet. One boulder is mentioned as being forty-two by forty by twenty feet in dimensions. The highest Laurentian boulders seen were at an elevation of forty-six hundred and sixty feet, on the base of the Rocky Mountains. The boulder clay, when thick, can be seen to be rudely stratified, and at one place includes beds of laminated clay with compressed peat, similar to the forest beds described by Worthen and Andrews in Illinois, and the so-called inter-glacial beds described by Hinde on Lake Ontario. The leaf-beds on the Ottawa River, and the drift-trunks found in the boulder clay of Manitoba, belong to the same category, and indicate that throughout the glacial period there were many forest oases far to the north. In the valleys of the Rocky Mountains opening on these plains there are evidences of large local glaciers

\footnotetext{
x "Memoir on Glaciers," Geol. Soc. Berlin, r88r. "Climatic Changes,"
} Boston, $188_{3}$. 
now extinct, and similar evidences exist on the Laurentian highlands on the east.

Perhaps the most remarkable feature of the region is that immense series of ridges of drift piled against an escarpment of Laramie and cretaceous rocks, at an elevation of about twenty five hundred feet, and known as the "Missouri coteau." It is in some places thirty miles broad and a hundred and eighty feet in height above the plain at its foot, and extends north and south for a great distance; being, in fact, the northern extension of those great ridges of drift which have been traced south of the Great Lakes, and through Pennsylvania and New Jersey, and which figure on the geological maps as the edge of the continental glacier,-an explanation obviously inapplicable in those western regions where they attain their greatest development. It is plain that in the north it marks the western limit of the deep water of a glacial sea, which at some periods extended much farther west, perhaps with a greater proportionate depression in going westward, and on which heavy ice from the Laurentian districts on the east was wafted sonth-westward by the Arctic currents, while lighter ice from the Rocky Mountains was being borne eastward from these mountains by the prevailing westerly winds. We thus have in the west, on a very wide scale, the same phenomena of varying submergence, cold currents, great ice-floes, and loca glaciers producing icebergs, to which I have attributed the boulder clay and upper boulder drift of eastern Canada.

A few subsidiary points I may be pardoned for mentioning here. The rival theories of the glacial period are often characterised as those of land glaciation and sea-borne icebergs. But it mu-t be remembered that those who reject the idea of a continental glacier hold to the existence of local glaciers on the high lands more or less extensive during different portions of the great pleistocene submergence. They also believe in the extension of these glaciers seawards and partly water-borne, in the manner so well explained by Mattieu Williams; in the existence of those vast floes and fields of current and tide borne ice whose power of transport and erosion we now know to be so great; and in a great submergence and re-elevation of the land, bringing all parts of it and all elevations up to five thousand feet suceessively under the influence of these various agencies, along with those of the ocean currents. They also hold that, at the beginning of the glacial submergence, the land wa: deeply covered by decomposed rock, similar to that which still exists on the hills of the southern states, and which, as Dr. Hunt has shown, would afford not only earthy debris, but large quantities of boulders ready for transportation by ice.

I would also remark that there has been the greatest possible exaggeration as to the erosive action of land ice. In I865, after a visit to the Alpine glaciers, I maintained that in these mountains glaciers are relatively protective rather than erosive agencies, and that the detritus which the glacier streams deliver is derived mostly from the atmospherically wasted peaks and cliffs that project above them. Since that time many other observers have maintained like views, and very recently $\mathrm{Mr}$. Davis of Cambridge and Mr. A. Irving have ably treated this subject. ${ }^{1}$ Smoothing and striation of rocks are undoubtedly important effects both of land glaciers and heavy sea-borne ice; but the levelling and filling agency of these is much greater than the erosive. As a matter of fact, as Newberry, Hunt, Belt, Spencer, and other have shown, the glacial age has dammed up vast numbers of old channels which it has been left for modern streams partially to excavate.

The till, or boulder clay, bas been called a " ground moraine," but there are really no Alpine moraines at all corresponding to it. On the other hand, it is more or less stratified, often rests on soft materials which glaciers would have swept away, sometimes contains marine shells, or passes into marine clays in its horizontal extension, and invariably in its embedded boulders and its paste shows an unoxidised condition which could not have existed if it had been a sub-aërial deposit. When the Canadian till is excavated and exposed to the air, it assumes a brown colour. owing to oxidation of its iron; and many of its stones and boulders break up and disintegrate under the action of air and frost. These are unequivocal signs of a sub-aqueous deposit. Here and there we find associated with it, and especially near the bottom and at the top, indications of powerful water-action, as if of land torrents acting at particular elevations of the land, or heavy surf and ice action on coasts; and the attempts to explain these by glacial streams have been far from successful. A singular objection sometimes raised against the sub aqueous

x Proc. Bost. Soc. Nat. Hist. xxii. Fourn. Geol. Soc. Lond., Feb., $188_{3}$. origin of the till is its general want of marine remains, but this is by no means universal ; and it is well known that coars: conglomerates of all a res are generally destitute of fossil-, except in their pebbles; and it is further to be observed that the conditions of an ice-laden sea are not those most favoura le for the extension of marine life, and that the period of time $\mathrm{c}$ )vered by the glacial age must have been short compared with that represented by some of the older formations.

Thi: last consideration suggests a question which might afford scope for another address of an hour's duration,- the question how long time has elapsed since the close of the glacial period. Recently the opinion has been gaining ground that the close of the ice age is very recent. Such reasous as the following lead to this conclusion : the amount of atmospheric decay of rocks and of denudation in general, which have occurred since the close of the glacial period, are scarcely appreciable; litıle erosion of river-valleys or of coast-terraces has occurred. The calculated recession of waterfalls and of production of lake-ridges leads to the same conclusion. So do the recent state of bones and shells in the pleistocene deposits, and the perfectly modern facies of their fossils. On such evidence the cessation of the glacial cold and settlement of our continents at their present levels are events which may have occurred not more than six thousand or seven thousand years ago, though such time estimates are proverbially uncertain in geology. This subject also carries with it the greatest of all geological problems, next to that of the origin of life ; namely, the origin and early history of man. Such questions cannot be discussed in the clusing sentences of an hour's address. I shall only draw from them one practical inference. Since the comparatively short post-glacial and recent periods apparently include the whole of human history, we are but new comers on the earth, and therefore have had little opportunity to solve the great problems which it presents to us. But this is not all. Geology as a science scarcely dates from a century ago. We have reason for surprise in these circunstances that it has learned so much, but for equal surprise that so many persons appear to think it a complete and full-grown science, and that it is entitled to speak with confidence on all the great mysteries of the earth that have been hidden from the generations before us. Such being the newness of man and of his science of the earth, it is not ton much to say that humility, hard work in collecting facts, and abstinence from hasty generalisation, should characterise ge ologists, at least for a few generations to come.

In conclusion, science is light, and light is good; but it must be carried high, else it will fail to enlighten the world. Let us strive to raise it bigh enough to shine over every oustruction which casts any shadow on the true interests of humanity. Above all, let us hold up the light, and not stand in it our:elves,

\section{UNIVERSITY AND EDUCATIONAL INTELLTGENCE}

Dr. Matthew Hay, assistant to the Professor of Materia Medica in the University of Edinburgh, has been appointed to the Chair of Medical Losic and Medical Juris rudence in the University of Aberdeen, vice Prof. Ogston resigned.

THE constitution of the College for North Wales, which is to be established at Bangor, having been approved by the Education Department, arrangements are actively progressing for its opening in January, in order to secure the amnual grant of $4 \mathrm{cool}$. which has been offered by Government. As in South Wales, temporary premises will be acquired, and possibly the Masonic Hall, a commodious building lately erected by Major Platt, will be so utilised. Nothing definite is yet arranged as t) the site of the College; but it is understood that Lord Penthyn, who bas evinced a very active interest in the movement, and to whom will probably be offered the honour of being first president, will afford every facility to the executive committee. About 30,000 . has been promised in subscriptions towards the building fund.

\section{SCIENTIFIC SERIALS}

Journal of the Russian Chemical and Physical Society, vol. xv. fasc. 6.- On the action of haloidhydric acids upon oxymethylene, by B. Tischenko.-On the constitution of the waters that accompany naphtha and are ejected by mud volcanoes, by $\mathrm{A}$. Potilitzin.-On the formation of bromides of aromatic hydrocarbons by the action of bromine and bromide of aluminium on the volatile parts of naphtha, by G. Gustavson.-On the 